\title{
The Reception of Arturo Giovannitti's Poetry and the Trial of a New Society
}

\author{
Hester L. Furey
}

\begin{abstract}
The fact is that modern society rests only on appearances and illusions, and derives its raison d'etre not from the existence or non-existence of certain things, but on the general accepted credence that these things do or do not exist. Truth becomes a menace to society and hence a crime, not when it is seen and felt by personal experience, though everybody see and feel it, but only when it is told ... It is the wisdom of the ostrich, say you. No, by all means - it is the wisdom of Argus who sees everything with his hundred eyes and knows that the only thing that can oppose the spreading of a truth is the spreading of a lie.
\end{abstract}

Arturo Giovannitti, Introduction to Emile Pouget's Sabotage

Arturo Giovannitti (1884-1959) has often been called a "poet of the workers" because his poetry played a significant role during the 1912 Lawrence Woolen Mills strike. His reputation as a poet and an organizer for the Industrial Workers of the World (IWW) was facilitated, ironically enough, by his trial and acquittal as an accessory to the strike-related murder of Anna LoPezzi, a Lawrence worker. During the intervening ten months between the arrest and the trial, Giovannitti and his fellow organizer Joseph Ettor drew a significant amount of public attention and sympathy as the persecuted representatives of immigrant labor. This period marks the beginning of a dozen years when Giovannitti enjoyed some standing in literary circles. This essay is an attempt to delineate only one set of the Lawrence Strike's consequences - to describe a few of its effects on American literary history. Perhaps no twentiethcentury literary career illustrates better than Giovannitti's the fact that evaluations of literary worth are made in a matrix of conversations about moral and political values, affected by shifting interpretations of public events, and inseparable at times from assessments of authorial character.

Looking at his poetic career generally, we might more properly call Arturo Giovannitti a poet of the judicial system. Throughout this period of success, which coincided with the period of the American Radical left's largest popular following and most frequent engagement with the courts, he laid bare the oppressive structures and dynamics implicit throughout the American criminal justice system, dispersing information and interpreting judicial practices with a gaze both worldly and compassionate. Early examples of this educational work in verse - "The Walker," "The Cage," and "The Prisoners' Bench" - were written in Massachusetts' Essex County Jail when he still believed he might receive the death penalty; later prose work to this purpose appeared in the Liberator - "Scott Nearing Reprieves Democracy," "Communism on Trial," and "Selecting a Perfect Jury." 
The son of an Italian doctor, Giovannitti had lived in Campobasso, Italy until the age of 16, attending Campobasso College before emigrating to Canada in $1900 .{ }^{1} \mathrm{He}$ attended McGill University and was ordained as a Protestant minister. In this capacity he worked on the railroad. Within a few years he moved to the United States, working as a coal miner and minister in Pennsylvania before moving to New York in 1906 . He continued his education in the United States, attending Columbia for a year. In 1908 he became the secretary of the Italian Socialist Federation of New York, and in 1909 the editor of its newspaper, Il Proletario. At some point in these years he moved away from the Social Gospel and affiliated himself with the IWW - of which the ISF was a supporting organization - and with Greenwich Village radicals, remaining with the IWW until 1916 and working with Masses-Liberator circles as a contributing editor until the end of the Liberator in 1926. In 1923 he helped found the Anti-Fascist Alliance of North America, serving as its secretary. Solon De Leon's 1925 American Labor Who's Who notes that "During the past 15 years [Giovannitti] has taken part in practically every strike of importance in which Italian workers were involved." Around the same time he began work as general secretary of the Italian Labor Education Bureau; he continued in this role until the 1940s. He also worked as an organizer for the International Ladies' Garment Workers' Union - as an honorary member of Local 48 - and the Amalgamated Clothing Workers' Union - as foreign language editor of its journal, Advance. ${ }^{2}$

1 Solon DeLeon (ed.), The American Labor Who's Who (New York 1925), 85. Looking back, it is very difficult to find information about Giovannitti's personal life, or even about his public life, beyond his role in the Lawrence Strike. His obituary in the New York Times lists his primary occupation as a poet, then summarizes his part at Lawrence, mentioning "The Walker" in that context, briefly notes critical acclaim given his work, and concludes with a vague, appearance-oriented account of Giovannitti's subsequent career in labor activism: "At the fiery labor rallies of the Nineteen Twenties and Thirties Mr. Giovannitti was in great demand as a speaker. A colorful figure, with a Van Dyck beard, a Lord Byron collar and flowing tie, he addressed Italian and English-speaking audiences with equally flowery fluency." "Arturo Giovannitti Dies at 75; Poet, Long-Time Labor Leader," New York Times 1 January 1960, 19:4. Among leftists he is remembered primarily in terms of this episode in the left's narratives about itself. Max Eastman remembers that "The phrase 'Ettor and Giovannitti' was almost as common as 'Lenin and Trotsky' on the lips of American radicals in those days," but his representation of Giovannitti after the Liberator fades into a suggestion that the poet/organizer somehow moved away from the "correct" circles and was never really himself after this moment (a fairly serious accusation given that Giovannitti lived for almost forty years afterward). Max Eastman, Love and Revolution (New York 1964), 76.

2 Wallace P. Sillanpoa, “Arturo Massimo Giovannitti” in Francesco Cordasco (ed.), Dictionary of American Immigration History (Metuchen, N.J. 1990), 254-255; Lydio F. Tomasi, Italian Americans: New Perspectives in Italian Immigration and Ethnicity (New York 1985), 232; Solon DeLeon (ed.), The American Labor Who's Who, 85-6; "Prison Life of Ettor and Giovannitti," Literary Digest, 14 September 1912, 442; Gary Fink (ed.), Biographical Dictionary of American Labor Leaders (Westport, CT 1974), 124; Luciano Iorizzo \& Salvatore Mondello, The Italian-Americans (New York 1971), 85, 199. 


\section{The Poetry of Judgment}

The meaning of Arturo Giovannnitti's work is accessible when read apart from the context of the Lawrence strike, but for a full sense of its actual accomplishments and an understanding of the significance of its absence from the traditional canon of American literature, its role in public life during debates about the meaning of the Lawrence strike must be taken into account. The 1912 strike was the most well-publicized and successful instance of IWW strike organization, although the IWW was called in after roughly 23,000 mill workers spontaneously struck in response to a pay cut. It began in January 1912, when woolen mill workers left their jobs in protest against a reduction of wages. The facts, briefly, are as follows. A new 54-hour work week law for women and children had just gone into effect in Massachusetts, and contrary to the policy that was established with a previous state reduction in hours, mill owners maintained that they must reduce wages accordingly, although they promptly speeded up machines to ensure that the amount of labor remained the same. ${ }^{3}$ Guided by the IWW, the workers formed a strike committee of two representatives from each national group and demanded a fifteen percent increase in pay on a fifty-four-hour week, double pay for overtime, and no blacklisting or other recriminations against workers after the strike. Mass picketing drew violent overtures from local militia and mill guards; when workers responded in kind, the governor of Massachusetts called in the state militia and state police. At the end of January Anna LoPezzi, a striker, was shot and killed by the police, and IWW organizers Ettor and Giovannitti were charged as accessories to murder on the grounds that they had incited the workers to riot with their speeches. ${ }^{4}$ The authorities then declared martial law, and Bill Haywood, William Trautmann, Elizabeth Gurley Flynn, and Carlo Tresca came to Lawrence to represent the IWW. In February about 200 children of strikers were sent to foster care with New York socialists under the supervision of, among others, a young nurse named Margaret Sanger. When 150 more children assembled to leave on 24 February, they and their mothers were surrounded and brutally prevented from departure by fifty policemen and two militia companies. This event and subsequent public outrage eventually led to a Congressional investigation that began in early March, and by the end of March the Lawrence mills had given in to all of the workers' demands and 250,000 people received pay raises as an indirect result. ${ }^{5}$ The actual strike, then, lasted only two months, but reverberations continued

3 Melvyn Dubofsky, We Shall Be All: A History of the Industrial Workers of the World, 2nd ed. (Urbana 1988), 227-28, 249; Joyce Kornbluh (ed.), Rebel Voices: An IWW Anthology (Chicago 1988), 159.

4 Sillanpoa says an agent provocateur did it, but Kornbluh and Cameron accept worker testimony that a police officer shot her.

5 Kornbluh, Rebel Voices, 162. Interpreted in the context of strike history, the victory was a temporary one. The Paterson Silk Strike of 1913 was not so successful. Kornbluh observes that "a fifty percent speedup of the textile machines after 1912 led to widespread unemployment and offset the wage increases that had been gained by the strike settlement." Joyce Kornbluh, "Introduction," in Gibbs Smith, Joe Hill (Salt Lake City 1969), 10. However, 
for an entire year, and the significance of the strike reached far beyond what this severely circumscribed account conveys.

Of course the irony is that the state had reduced workers' hours in response to public concerns about their health and working conditions. Testimonies of physicians and workers at the Congressional hearings emphasized the fact that "Half of all the workers in the four Lawrence mills of the American Woolen Company were girls between the ages of fourteen and eighteen," and "thirty-six out of every 100 of all the men and women who work in the mill die before or by the time they are twenty-five years of age." ${ }^{6}$ However, the reduction in pay put a further strain on an already tenuously maintained existence, as Ardis Cameron's retrospective study of the strike demonstrates: "Several women recalled the Lawrence strike as "the strike for three loaves,' and most remembered not only that the pay was short, but that it was precisely thirty-two cents short," or the price of three loaves of bread. ${ }^{7}$

The strike was remarkable for two reasons. First, as indicated above, women's issues and women activists reached and maintained an almost unprecedented degree of public notice. Women started the strike - Polish women at the Everett mills were the first to walk out, crying "short pay!" Violent, defiant, "unwomanly" acts by women strikers and strike supporters provoked turbulent emotions among journalists covering the strike, as formerly obscure community leaders became pro-union activists. ${ }^{8}$ The major events of the strike occurred when Anna LoPezzi was shot and when strikers' children were kept in Lawrence by force; these incidents combined to create the general impression that the foundations of civilization itself - the delicacy of womanhood and the sacred right of parents to govern the actions of their own families - were at stake, as well as eliciting widespread moral outrage, exacerbating the original conflicts in Lawrence, generating nationwide sympathy for the workers, and provoking a Congressional investigation.

The second reason the strike made such an impression is that, because the striking workers claimed about 30 different places of national origin, including Syria, Italy, Armenia, France, Belgium, and Germany, Lawrence simultaneously raised anxieties about the role of immigrants in America and affirmed national hopes about the possibility of cross-cultural cooperation; the strike forced a confrontation of the limits of American faith in and desire for "the melting pot." After the workers walked out, they called for the IWW to help run the strike, as much a pragmatic decision as an ideological one - since the IWW's goal was to organize categories of workers

here, as elsewhere, my argument remains that assessments of the IWW's success or failure must take into account the primacy of its goal of making a change in working-class consciousness, as well as working conditions in the strikes it organized.

6 Kornbluh, Rebel Voices, 158-59.

7 Ardis Cameron, "Bread and Roses Revisited: Women's Culture and Working-Class Activism in the Lawrence Strike of 1912," in Ruth Milkman (ed.), Women, Work and Protest: A Century of U.S. Women's Labor History (Boston and London 1985), 49.

8 Cameron, 52-54; Ardis Cameron, Radicals of the Worst Sort: Laboring Women in Lawrence, Massachusetts, 1860-1912 (Urbana 1994). 
scorned by more traditional unions, this organization was undoubtedly the best prepared to deal with a multilingual work force. It provided Lawrence workers with Joseph Ettor, who could speak English, Italian, and Polish fluently and could understand Hungarian and Yiddish, and Giovannitti, fluent in English, Italian, and French. The level of cooperation among workers in this potentially explosive situation was a powerful statement of something that more well-established Americans were not at all sure that they liked, especially given the IWW's annoying habit of claiming moral values that "better," more "respectable" people liked to think of as exclusively their own. ${ }^{9}$ The fact that the two most prominent organizers were Italian could not have reassured the mainstream. When anarchist Carlo Tresca led a spectacular September parade of 3,000 to honor the murdered Anna LoPezzi and to arouse sympathy for the jailed Ettor and Giovannitti, banners of "No God, No Country" or "No God, No Master" inspired Catholic priests in Lawrence to lead Irish and French-Canadian workers in "God and Country" demonstrations. ${ }^{10}$ Notably, Catholic workers' support for American values in turn sparked vicious displays of nativist hostility from more established citizens.

The general consensus among journalists covering the strike was that it made deep and lasting changes in workers' consciousness. The liberal Ray Stannard Baker expressed misgivings about the IWW leadership but was clearly charmed by the workers and their enthusiasm; he concluded that "finally, one comes away from Lawrence feeling deeply and profoundly that this problem is no mere hard economic question." "Mary Heaton Vorse, a lifelong radical then working as a journalist, with ties to Greenwich Village and the IWW leadership, had more definite ideas about the strike. In "The Trouble at Lawrence" she argues that, aside from economic effects,

9 The best example of this strategy is the Industrial Workers of the World's Little Red Songbook or Songs of the Workers. As I have argued elsewhere, although IWW songwriters have been called "unoriginal" because they rewrote popular, religious, and patriotic songs to suit their needs, this practice in fact represents a series of careful choices. To win workers over, the IWW had to recodify existing power relations in such a way that the revision relied upon workers' own memories and common-sense. IWW songwriters have traditionally had a talent for paradox, using widely accepted and respectable moral languages which were readily available to workers to argue for the radical positions of class consciousness and unionization. For example, Joe Hill's parodies of Salvation Army songs claim the apocalyptic language of the songs even as they ridicule its source. The IWW's religious irreverence created oppositional communities in which workers felt entitled to a voice and were encouraged to be authors of their own destinies rather than helpless creatures of "the boss who pays starvation wages." For more detail, see Hester Furey, "'Raising the Specter': Poems and Songs of the American Radical Left, 1880-1920" Ph.D. thesis, University of Illinois, 1992, 84-132. Giovannitti's poem, "At the Prayer Meeting" is also an exemplary text. Here the speaker explains himself to God by paradoxes for "devoutly disregarding thy command" (to turn the other cheek): "I bade men rise, and thus I saved thy word,/ I bade them strike, and thus upheld thy rule!" Collected Poems of Arturo Giovannitti, (Chicago 1962; New York 1975), 39-41.

10 Donald Cole, Immigrant City: Lawrence, Massachusetts, 1845-1912 (Chapel Hill 1963), 195-97.

11 Ray Stannard Baker, "The Revolutionary Strike," American Magazine, May 1912, 19-30. 


\section{2 left history}

there are 20,000 people there who, whatever else happens, can never again have the race hatreds and creed prejudices that they did before they learned what working together may mean ... Young girls have had executive positions. Men and women who have known nothing but work in the home and mill have developed a larger social consciousness. A strike like this makes people think. ${ }^{12}$

Ideologically, the events at Lawrence gave the IWW the largest threshold of influence it has ever had on mainstream American culture and public opinion. The length of time the IWW was able to maintain a continuous mainstream media presence - an entire year, since the strike began in January, the Congressional hearing was held during the summer, and publicity on the approaching Ettor-Giovannitti trial picked up steam in September and continued through January 1913 - lessened the strangeness of the organization and made its perspectives more acceptable. ${ }^{13}$

Consequently, even when writers issued vehement disclaimers and censured IWW agendas (vaguely perceived to be of sinister and violent character) in their interpretations of the situation at Lawrence, they sometimes showed evidence of having been influenced by IWW ideas on social policy. Even the U.S. Labor Bureau Report on the strike at Lawrence discusses the strike's social significance and treats the IWW presence there without alarm, including the IWW Preamble in its entirety and reflecting soberly that "the Lawrence strike ... became ... more than an industrial strike, and within the territory of its activities, took on some of the aspects of what might be termed a social revolution." ${ }^{14}$ An event clearly defined in association with the IWW had been universally agreed upon as a sign of long-term social change, and the IWW could no longer be easily dismissed.

Part of the discursive process through which this idea grew occurred in discussions of Giovannitti's poetry among literary reviewers for magazines such as Survey, Literary Digest, and Current Opinion. Much of the poetry that appears in Giovannitti's first book, Arrows in the Gale, is a response to the strike. Generally, it fostered belief in the above interpretation of the strike; specifically, it worked to mobilize workers at Lawrence and elsewhere. Notably, these poems were not "jingles," easily memorized hymns, or in any way vehicles for the propagation of slogans - "The Walker" and "The Cage" are modernist long poems. Part of their work is to establish - in the minds of the general public and of workers themselves - that working-class people are entitled to leisure, reflection, and participation in high culture.

During the strike and in the months leading up to the trial, Giovannitti's poetry worked within the contexts of IWW propaganda and mainstream journalism to revise existing conceptions of "law and order," critiquing the disciplinary technologies of jail and court-room and noting overlaps between these and the work-place. In

12 Mary Heaton Vorse, "The Trouble at Lawrence," Harper's Weekly, 16 March 1912, 34.

13 It must be noted here that this moment in the sun did not last for long. Anti-IWW feeling, strengthened by the union's opposition to American participation in World War I as well as more generalized distrust of the left, soon led to a new round of trials.

14 U.S. Labor Bureau, Report on Strike of Textile Workers in Lawrence, Mass, in 1912 (Washington, D.C. 1912), 17. 
particular Giovannitti's poems foreground the contradiction between his society's supposed value of individual fulfilment and inner life and that society's investments in capitalism - he insists that workers have souls. Once in circulation, the poems came to be read not only as emblems of Ettor and Giovannitti in the Essex County jail, but of the plight of unskilled workers subject to the whims of capitalism, in Lawrence and all over the world. In this scenario the IWW became the champion of workers' human rights. Using the image of a jail to stand for all dehumanizing physical and mental systems of containment and restraint, the poems play on early twentieth-century ambivalence about modernity, arguing on the one hand that "the supreme wisdom of the jail" is a holdover from the unenlightened past, and on the other evoking the horror of a future in which our subjection to its judgment will change us from humans to "so many appendages of machines." 15 Together "The Walker" and "The Cage" depict a romanticized human nature in the fetters of capitalism and implicitly promise a free "new society" with the IWW.

"The Walker" critiques rationalist technologies of knowledge, calling into question the dominant "keys" or analytic languages and noting their inadequacy for meeting human needs. ${ }^{16}$ In an ironic reversal of the romantic poet's perspective on humanity from "on high," the voice of this poem comes to us from what seems like a grave: "I hear footsteps over my head all night." The poem opens in the emblematic darkness and unrest of a demonic parody of justice; it is night and neither the speaker nor his "brother" the walker can sleep for despair. The beginning foreshadows the conclusion by immediately contrasting the finite nature of the prison with the "transcendent" spirit of those held there. It starts with one image - a man pacing around a prison cell - and moves quickly, like the walker himself, in four steps or lines, to the suggestion that something much less easily managed is at work in this image. Although the speaker can hear only the walker, tracing and re-tracing the limits of the space where he is confined, he says that the walker's footsteps "come one eternity in four paces and ... go one eternity in four paces, and between the coming and the going there is Silence and the Night and the Infinite." Such lines make explicit the title's understatement: simple, ordinary acts are only the most visible outer signs of unknown inner worlds, and a truth that accounts for only the surfaces is no good for the needs of complex beings, "thinking things that cannot be chained and cannot be locked, but that wander far away in the sunlit world, each in a wild pilgrimage after a destined goal."

Next the speaker compares the walker's "grave march" of repeated, regular actions to the clock's, remarking along the way that "the old clock which marks everything ... the wise old clock that knows everything, does not know the number of the footsteps of the Walker, nor the throbs of my heart." The language here

15 This refers to Ettor's address to the jury. Ettor and Giovannitti Before the Jury at Salem, Massachusetts November 23, 1912 (Chicago [1913]), 26.

16 I quote here from The Collected Poems of Arturo Giovannitti, intro Norman Thomas (Chicago 1962; New York 1975). 
anticipates Giovannitti's remark to the jury at his defense: "The District Attorney and the other gentlemen here who are used to measure all human emotions with the yardstick may not understand the tumult that is going on in my soul in this moment." 17

As a gesture to counter the regulation of social space associated with the cell and the clock, the speaker offers a series of paradoxes. First, he dissects and catalogues the various kinds of silence he hears in his "wistful vigil." In his vision men are imprisoned and silenced by loss, insurmountable obstacles, pride, religion, madness, and physical illness, and thus when he hears any signs of resistance, such as curses, "I listen ... in reverence and awe, for they are holier than the virgin's prayer." Finally, the "most terrible" sound to him is "the silence of two hundred brains all possessed by one single, relentless, unforgiving, desperate thought," the frustration of which is only expressed in "the footsteps I hear over my head all night."

Giovannitti describes the walker's single thought as "constant, fixed, immovable, sinister, without power and without voice" continually centred on an unreachable object, freedom, but as ironically embodied in "the most superhuman, the most unattainable, the most impossible thing in the world ... a small brass key" to open the gate. The key represents an overly simple solution to a problem (such as the capitalist idea that money and the joys of consumerism are the measures of a meaningful life). As the speaker notes, this very key or symbol of freedom keeps the walker enthralled and internalizing the conformity imposed by his environment. Imagined possession of it supersedes all other values, and the ubiquitousness of its presence in the prisoners' imaginary must be understood as itself central to the maintenance of the jail. The speaker describes himself as an example of the ironic unity or arbitrary levelling created by the keeper of the key, and bitterly praises its power:

Wonderful is the supreme wisdom of the jail that makes all think the same thought. Marvellous is the providence of the law that equalizes all, even in mind and sentiment. Fallen is the last barrier of privilege, the aristocracy of the intellect. The democracy of reason has levelled all the two hundred minds to the common surface of the same thought.

The speaker concludes that those who have been reduced, or as he says, "congealed" to a key have given over their wealth and power as well as their essence, to "the pocket of a white-haired man dressed in blue." The key is "the mighty talisman ... the monstrous cabala that can make the apostle and the murderer, the poet and the procurer, think of the same gate, the same key and the same exit on the different sunlit highways of life." Ultimately the key represents, not physical freedom, but an imprisoning system of truth. ${ }^{18}$

17 Ettor and Giovannitti Before the Jury, 55.

18 An alternate reading which nonetheless supports my reading of "The Walker" 's conclusion appeared in the 15 August 1912 issue of the Industrial Worker in the form of a political cartoon which portrayed Ettor and Giovannitti in jail; the lock on their door is designated "Capitalism," and a man outside the jail (labelled "Labor") is bending to pick up a key, which is explained by the caption: "The General Strike is the Key That Fits the Lock to 
The poem concludes with a plea to the walker: "Stop, rest, sleep, my brother, for the dawn is well nigh and it is not the key alone that can throw open the gate." Indeed, "the key alone" will leave the jail in place.

The technique of using a single image to reinterpret those larger technologies of power which dispense truth and are supposed to offer freedom also structures "The Cage," a reading of the courtroom said to be written at the request of Big Bill Haywood, who asked Giovannitti to write "something about sixteenth-century courts trying to solve twentieth - century problems." ${ }^{19}$ In "The Cage" Giovannitti takes up "The Walker"'s assertion that "All things natural are things impossible while there are jails in the world - bread, work, happiness, peace, love." The voice of the poet changes from the lyric " $\mathrm{I}$ " in isolation to become more inclusive and to reflect more points of view. Countering the enemy's ability to make two hundred men focus on a single thought at once, "The Cage" gives the suppressed voices of "The Walker" a space and meditates on the process by which industrial progress has imprisoned people rather than liberating them.

At first the opposition between the courtroom and "nature" seems a simple one. In the courtroom,

All was old, and cold and mournful, ... and their faces were drawn and white and lifeless ...

For of naught they knew, but of what was written in the old, yellow books. And all the joys and the pains and the loves and hatreds and furies and labors and strifes of man, all the fierce and divine passions that battle and rage in the heart of man, never entered into the great greenish room but to sit in the green iron cage.

Nature enters this courtroom only to stand trial. Clearly, this "fireless," "godless," "mouldering," "dusty," "dead," and "lifeless" scene has nothing to do with the young men in the cage, who are from the outside, where "Wonderful and fierce was the mighty symphony of the world, as the terrible voices of metal and fire and water cried out into the listening ears of the gods the furious song of human toil." In the green room no one can hear the song outside except the men in the cage. Likewise, "All the good smells, the wholesome smells, the healthy smells of life and labor were outside the great room," except for "the breath of the three men in the cage."

The three men in the cage set about puzzling over the "strange" case - "that they should be there because of what dead men had written in old books": "Which of these two powers has enthraled us, the thought of the dead men who wrote the old books, or the labor of the living men who have wrought this cage?' How does the cage have the power to hold them? One of the men has a paradoxical answer: the cage draws its power from the same source as the key to the jail of "The Walker" although these things have been turned against people, the people who made them desired freedom: "Brothers, it is the things we love that enslave us." The workers'

Freedom," Industrial Worker, 15 August 1912.

19 Kornbluh, Rebel Voices, 187. 
desire for a better life has been appropriated and turned into a prison. At this point the iron in the cage itself breaks in, protesting that its presence as a cage is no more natural than the men's presence there - its original purpose was "Not to imprison thee, but to set thee free and sustain thee." It has risen against man because it has been made "the lackey of gold," and it argues, "My curse is thy curse, O Man." The iron urges the men to reclaim and transform the material world..$^{20}$

Like "The Walker," this poem is about listening to the jail and understanding what it says about society, and both poems are diametrically opposed to the regime of "reason." Both poems denaturalize law and order, denouncing the "rationalization of space" as the regime of dead men and celebrating the material world's disruptive forces. The contradiction in the dominant order is that it defines life and peace as chaos, whereas death or an approximation of it passes for order.

At one level the poems function as a call to the general strike, in accordance with IWW portrayals of the situation in Lawrence as "the trial of a new society." But in the continuing rhetorical struggle over the moral centre in Lawrence, there are several alternating contents of the term "new society": among them the syndicalist utopia desired by the IWW and the modern technologies and consumer society of the advancing twentieth century, to which we still have such an ambivalent relationship. At times Giovannitti's poems celebrate industrialism, unlike so many modernist poems, but to the extent that capitalism is rooted in the old logic of "law and order," his poems function primarily to condemn. The combined effect of these particular poems is to convict the justice system of imposing a murderous conformity on thought; they resonate with the sentiment expressed in Giovannitti's address to the jury, that "if ever there has been murder in the heart of a man in this courtroom, that man is not in this cage." Finally, the fundamental injustice they depict undoubtedly rang true to textile workers in Lawrence on two levels: the condition of their everyday lives was not included in the definition of violence when condemnations were being handed out by the media and the courts, whereas their threat to the profits of the mills was seen as a great crime; also, like striking workers everywhere, they were held responsible for the violence attending the strike although they were clearly outgunned by the armed agents of the state.

Giovannitti's poetry of this period and IWW efforts to underscore his identity as a poet provide instructive examples of the IWW's strategies to influence public opinion. Part of Giovannitti's public role was to signify the civilized intentions of the IWW, to demonstrate the membership's finer feelings and appreciation for culture with a capital $\mathbf{C}$, and to give an index of how much the IWW had been misrepresented by the capitalist press. The emphasis on his poetry also worked to counter his dangerous ethnic and political identity. The publicity surrounding Giovannitti's trial focused on this peculiarity in his situation, the perceived contradiction between his

20 Giovannitti's most obvious sources for this mystical materialism or allegorical sensibility are the Romantic poets whom we know he read: Byron and Shelley (more specifically, "Manfred" and "Prometheus Unbound"). 
respectable sensibility as a poet and his membership in the rough and disreputable Industrial Workers of the World. Yet Giovannitti was sufficiently persuasive at making his case for the interrelationship of these roles that he posed, quite premeditatedly, a threat to the secure patriotism of liberal/conservative poetry critics. ${ }^{21}$

His talent for lyrical drama and his mythographic tendencies drew them to his work, but his work had a nasty and uncompromising way of connecting politics with inner beauty, taking logics of the "universal subject" so dear to poetry critics and carrying them to their shockingly democratic extreme. Consequently critics found themselves in something of a bind: their stature as thinking people demanded that they have something to say about his work, but the words and images themselves were inescapably charged with political meaning; sentiments long felt the exclusive province of respectable, law-abiding citizens had been claimed for " anarchists," and critics had to negotiate their way through poems like mine fields, or they might turn out to have insurgent sympathies. The dangers were many. They could not contest his poetry's claims about the dehumanizing nature of the legal/penal apparatus. More aggravatingly, this poet marshalled with ease the languages of humanism, Christianity, vanguardism, progressivism, and nationalism, using them to steal the moral centre of industrial democracy for the workers and their union. Worst of all, the success of his poetry provided evidence for the truth of the traditional American left defense of free speech revived by the IWW, the argument that idealists, not murderers, were on trial.

\section{Judging the Poet}

From 1912 to 1914 it was hardly possible to read Giovannitti's poems without recalling his public persona as an IWW organizer and his dramatic defense to the jury. Shrewdly drawing attention to the qualities of character that made Giovannitti an unlikely occupant of a jail cell, the IWW conducted a publicity campaign in the months leading up to the trial — ostensibly directed at the issues of the approaching trial but with far-reaching implications -- to focus public scrutiny on and insinuate

21 My use of the term "liberal/conservative" is intended to point out one of the crises provoked by Giovannitti's poetry among liberal mainstream critics. Alongside Giovannitti's radical politics, differences of degree among respectable people who liked the sound of his poetry but still believed in God, country, etc., became diminished. Liberals qualified their praise of Giovannitti's poetry by rushing to identify with the political right or by trying to recuperate the poetry into such safe, socially accepted narratives as "the natural rebelliousness of youth." Giovannitti's poems tried the audience in more ways than one, and it is notable that, in a moment of forced polarization, most of the liberal critics of his time felt more comfortable emphasizing their commonalities with the right than with the left. As I suggest later, the Atlantic could safely open the discussion of Giovannitti's poetry after the trial because, as a conservative journal, its politics were not in danger of being misunderstood. Similarly, I use the term in my discussion of discursive struggles around the trial to underscore the basic conservatism of "liberal" journalists who argued that the courts exonerated themselves in acquitting Ettor and Giovannitti instead of realizing that the men should never have had to stand trial at all. 
doubts about the American criminal justice system. Workers in Lawrence went back to the picket lines in a sympathy strike. In Italy Giovannitti was nominated for the Chamber of Deputies in three districts. The International Socialist Review for September opened with "The Walker" and included a manifesto of the Young Socialist Party of Sweden which urged a sympathy boycott of all American goods and encouraged transport workers to refuse all work connected with vessels arriving from or travelling to America. ${ }^{22}$ In the same month, the Literary Digest, noting that "prisoners sometimes rise far above their environment" reprinted an article from the Boston Herald on the "Prison Life of Ettor and Giovannitti." This account of Giovannitti's intellectual history and current choices of reading material - Taine's English Literature, Shakespeare, Shelley, Byron, Carlyle, Balzac, and Kant (The Critique of Pure Reason) was widely quoted, and helped solidify Giovannitti's image as a wise man misjudged. Already the case was being compared to the Haymarket incident. $^{23}$

Giovannitti's reputation as a writer of verse also began to pick up while he was in jail - the International Socialist Review published some of his poems ("The Republic" in July and "The Walker" in September 1912), and by November, just before the trial, the poetry had found its way into such forums as the Survey and Current Literature. Immediately prior to the trial one of the most moving and sympathetic reviews of his poetry appeared in the Survey. Meditating on what it means that "We in America today are quick to respond to the poet of a Russian dungeon who sings of the wrongs of Russian peasants," Mary Brown Sumner asks, "But what of a lyric singer in a New England jail, whose arraignment of American democracy would put it on a par with Russian despotism?" Engaging in her own poetry, she concludes with a portrayal of Giovannitti as the poet of the "seat of poverty," pointing to his poems, "The Prisoner's Bench" and "The Bench in Mulberry Park," and pleading, "Surely we are not so rich in lyric poets that we can afford to send this one to the chair ..." ${ }^{24}$ At this point Giovannitti's poetry signified something inseparable from his character. Its first presence, then, was as evidence in his defense before the "jury" of public opinion.

Giovannitti's subsequent conduct during the trial confirmed the growing sentiment in his favor. Both defendants were allowed to speak to the jury at length on their own behalf. This gave Giovannitti the opportunity to speak for the first time to a mainstream American audience. Appealing with remarkable success to their favorite stories about themselves, he portrayed himself as an immigrant in search of a better life in a romanticized America and argued:

22 General Executive Board, Young Socialist Party of Sweden and the Central Organization of Swedish Workers, "Shall Ettor and Giovannitti Be Murdered?" International Socialist Review, September 1912, 245-6.

23 "Prison Life," in The Literary Digest, 14 September 1912, 441, 443.

24 Mary Brown Sumner, "Arturo Giovannitti," Survey, 2 November 1912, 163-6. 
Had not this last appeal to patriotism been injected ... had not the District Attorney appealed to you ... in the name of all the feelings that are deep-rooted and sweet to the heart of man, in order to blind you to the real issues in this case, I would not have spoken ... but I want to say something about the kind of patriotism that is instilled into your heads ... it is tainted with a bad past, but was originally a resolution in favor of liberty, that a new people, a new theory, a new principle, a new brotherhood would arise out of the ruin and wreckage of the past. ${ }^{25}$

Characterizing the IWW's work as progressive, ennobling, and humanist at its core, he compared its vision of "the grand condition of tomorrow" to that of anti-slavery activists, who insisted that human beings could not be property:

I say it is the same principle now, the principle that made a man at that time a chattel slave ... which now, having changed the term, makes the same man - but a white man - the slave of the machine ... But I say that you cannot be half free and half slave ... the man that owns the tool wherewith another man works, the man that owns the house where this man lives, the man that owns the factory ... that man owns and controls the bread that man eats and therefore owns and controls his mind, his body, his heart and his soul.

Having evoked the ultimate American horror in this image of powerlessness and violated rights, he went on to prove himself a master of their religious prejudices. Hinting at American national identifications with and implications in Protestant history, (and playing in subtle ways on the audience's probable nativism), he repeatedly invited the audience and jury to see the IWW in a long history of enlightened and persecuted men whose ideas were "ahead of their time":

it may be that we are fanatics ... we are fanatics ... And so was a fanatic the Saviour Jesus Christ ... And so were all the philosophers and all the dreamers and all the scholars of the Middle Ages ... we have been working in something that is dearer to us than our lives and our liberty. We have been working in what are our ideas, our ideals, our aspirations, our hopes - you may say our religion, gentlemen of the jury ... we have come here to proclaim a new truth; we are the apostles of a new evangel, of a new gospel.

Thus the potential martyr, assuming the voices of Abraham Lincoln and Jesus, managed to encode his position such that, if jury members convicted, they would have convicted themselves by every moral code available to them of all the social crimes Americans predicate themselves against. Worse, both Ettor and Giovannitti refused the jury a middle ground. Giovannitti insisted that a verdict of "not guilty" would sanction further IWW efforts:

We shall return again to our humble efforts, obscure, humble, unknown, misunderstood - soldiers in this mighty army of the working class of the world, which out of the shadows and the darkness of the past is striving towards the destined goal which

25 Ettor and Giovannitti Before the Jury 59-71. Giovannitti's address was also published separately as Giovannitti's Address to the Jury (Boston 1913). 
is the emancipation of human kind, which is the establishment of love and brotherhood and justice for every man and every woman on this earth.

Ironically, by trying his oratorical skills in the courtroom and proving himself guilty of being an irresistibly persuasive speaker, Giovannitti convinced the jury (and more importantly, the press) that he could not possibly have inspired the strikers to violence, even if he was an Italian and a member of the IWW. Hardened journalists left the courtroom in tears, and the two men were found not guilty.

After the trial a discussion of Giovannitti's character arose as part of retrospective assessments of what Lawrence meant for the future. In January 1913, less than two months after the acquittal, Current Opinion reprinted selections from "The Walker" in an essay with the title, "The Social Significance of Arturo Giovannitti." ${ }^{26}$ Reflecting on the puzzle of his philosophical development, the essay argues that the existence of a Giovannitti does not bode well for America. The argument borders on social critique but is firmly grounded in respectable middle-class values; it is a useful analysis because it makes clear why even conservative critics were eager to contribute to Giovannitti's praise and have a chance to explain him. Solving the paradox of Giovannitti's association with the IWW by way of caricature ("He is not the usual type of labor agitator. The usual type is not a very complex one."), it emphasizes the character traits which are the unmistakable signs of greatness: "He has the soul of a great poet, the fervor of a prophet, and, added to these, the courage and power of initiative that mark the man of action and the organizer of great crusades." To be more to the point, he is educated, comes from a family with good social standing, and has a history of mission work in Montreal, Brooklyn, and Pittsburgh: "Three Protestant missions, therefore, were conducted by this man now a leader in a movement which blazons to the world its banners bearing the legend, "NO GOD, NO MASTER."' Arguing that a year of Giovannitti's life was not wasted in jail because "The Walker" is "a great human document," the essay concludes with a reference to his course of study while in jail and reiterates its earlier assertion that Giovannitti is "a social portent":

For it is surely an ominous thing that a young man of good family, well educated, markedly religious by nature, coming to this land in search of freedom and opportunity, actively associated with the church in its missionary work among the poor, should in a few years be transformed by his experiences into an extreme revolutionary, bitter against authority of all kinds, flouting the Constitution and denying God.

Although the article attempts to defuse Giovannitti's dangerous affiliation with society's undesirable elements by insisting that "he is far removed from the criminal type," the author cannot account for Giovannitti's "fall." The deep structures of the essay treat the poet as a Lucifer figure - he has everything to make middle-class critics want to recuperate him, but his unaccountable "turn" codes him as a sign of metaphysical vulnerability. Even the secure possession of solidly respectable values 
cannot keep us safe. In the end, the writer cannot quite finish the argument, cannot say what Giovannitti portends. ${ }^{27}$

Public knowledge of Giovannitti as a poet, then, had its beginning in journalistic fascination with his enigmatic personality. As Max Eastman pointed out, among bohemian circles the perceived paradoxes of his character were considered assets: "the fact that [Giovannitti], a 'labor agitator' grossly defiant of existing respectabilities and powers, should also turn out to be a poet in the classic style, chimed to perfection with the mood of the Masses and Liberator." 28 The earliest commentaries on his poetry appeared in the light of his impending martyrdom, and were uniformly generous in praise, even outside the radical left. Current Literature, for example, had remarked in introducing "The Walker" that "Poems in the manner of Whitman frequently are slavishly imitative, but this is original. It is sincere, graphic, memorable." ${ }^{29}$ His work received no bad reviews. Reviewers and editors compared him to Whitman, Shelley, Wilde, James Oppenheim, and William Vaughn Moody. Invariably, he won conventional poetry critics over and showed them poetry where they had seen none before - in jail, in the courtroom, on a bench in Mulberry Park. But there was, as Florence Converse pointed out later, no consensus about the "laws of poetic beauty," and Giovannitti's work exacerbated this problem since the poetry's origins in leftist social criticism were irrepressible.

Publicity surrounding the trial had called attention to the fact that it was held in Salem, Massachusetts, playing on all of the overtones of that town's significance in the history of the state, from patriotic evocations of New England's role in the nation's past and the attendant "traditional" values to the witch trials and burnings. ${ }^{30}$ Discussions of the Ettor - Giovannitti trial as "The Trial of a New Society" appeared across the social spectrum. After the trial the IWW had to produce a new way of reading his poems that took into account both their criticisms of the judicial system and the verdict of not guilty. The mainstream (liberal/conservative) press, predictably, took the opportunity to recuperate the trial into affirmations of pro-nationalist sentiment.

Liberal discussions of the trial appearing the week of 7 December 1912 invariably focus on the good conduct of the participants in the trial rather than the fundamental injustice of the fact that the trial had been held in the first place. In the Survey's account of "The Salem Trial," James P. Heaton takes up strands of the defense's arguments

27 In Something in Common - An IWW Bibliography (Detroit 1986), 286, Dione Miles summarizes the argument of the article with delightful humor: "Giovannitti is a real social portent because, despite his IWW connections, he is intellectual, poetic, and of good family. Does this mean there may be a real reason for revolution?"

28 Max Eastman, Love and Revolution (New York 1964), 76.

29 Current Literature, November 1912, 593.

30 This rhetoric would return a decade later to describe the case of Sacco and Vanzetti. Of particular note is a collection of poetry memorializing the case, America Arraigned!, edited by Lucia Trent and Ralph Cheyney (New York 1928). The collection includes three poems - Witter Bynner's "Once More, O Commonwealth!," Robert Whitaker's "The Culprit," and Edith Squires Lombard's "Massachusetts, 1667-1927" — which treat the Sacco-Vanzetti case as to some degree analogous to the Salem Witch Trials. 
and IWW assessments of the case to argue that the trial reaffirmed immigrant workers' belief in American democracy: "Now they had a new, potent embodiment of the old Bay State, not in the prosecution, but in the even tempered New England judge of the old school, and in the twelve 'good men and true' who sat, listened, and coolly made up their verdict." "3! It is common knowledge, he notes, that "the almost instantaneous recoil of the authorities" has endangered social stability nearly as much as the socialist agitation it reacts against. In this light, the trial has provided some security, "an abiding sense that American justice can weather times of industrial stress." Mainstream newspaper writers were very taken with the case, as the imagery of Heaton's conclusion suggests:

the old court crier, stocky of build as Joe Ettor himself, but clear-skinned, sharp-nosed and with the look of the fifer in the familiar prints of "The Spirit of "76"... droned the formula which has closed the sittings of the Massachusetts courts of even handed justice since the founding of the state ... "God save the commonwealth of Massachusetts."

However, as his use of the term "old" and celebration of tradition indicate, Heaton managed to extract from the trial exactly the opposite meaning from the one that Giovannitti suggested in "The Cage."

The Literary Digest of the same week includes in its summary a note of scepticism, implying that the Eastern daily papers are strangely "practically unanimous" in their coverage of the case; the sample opinions taken from a range of newspapers display in retrospect widespread disgust with and eagerness to disclaim "the authorities" at Lawrence, who had bungled the case so badly as to discredit themselves and "strengthen the antisocial element" everywhere. ${ }^{32}$ The Outlook, listing Theodore Roosevelt among its contributing editors, remarked "It is an occasion for thankfulness on the part of every decent, law-abiding American when our court methods for obtaining justice do withstand any severe shock"; the primary concern here seems to be that the courts had not been so successfully discredited as they had in the Haymarket case. Giovannitti and Ettor are still depicted as "agitators of an undesirable propaganda." 33

After the trial appreciation of Giovannitti's work among mainstream critics began to show signs of ambivalence. To some extent, the comparisons to more well known authors have to be read in this context of uncertainty and recuperation. Negotiating around political conflicts and implicit cultural contradictions, liberal/conservative critics sought a language which would allow them to grant his poetry the praise they felt compelled to give but which would secure a distinction between themselves and Giovannitti's undesirable politics. One of the first critical "events" of the period after the trial and before the appearance of Arrows in the Gale came when the Atlantic, a

31 James P. Heaton, "The Salem Trial," Survey 7 December 1912, 301-4.

32 "Acquittal of the 1.W.W. Leaders," Literary Digest, 7 December 1912, 1049-50.

33 "Salem Trial of the Lawrence Case," Outlook, 7 December 1912, 739-40. 
conservative monthly, published "The Cage" in June of 1913, much to the surprise and chagrin of more liberal journalists. ${ }^{34}$

In "The Contributors' Club" of that issue, an editor wrote that "if there is a poetry of anarchy, this is it ... whether the poem repels or attracts the reader, he will find in it ... more of the heart and soul of the Syndicalist movement than all the papers of all the economists can teach him." Secured by evidence that the law has "in it the spark of the eternal life of justice," the editor can afford to be generous, passing judgments which are alternately sophisticated, suspicious, and comically humane, as the following will indicate.

The philosophy of the poem sounds harshly materialistic, yet we must not forget that to the very poor, bread, bed, and sunshine may suggest something very different from materialism ... But even if the poem offers no suggestion of some evolution toward an idealism still to come, if sunshine and a chance to feel its warmth are really all these revolutionists desire, then to be shut away from it is to them at least an utter calamity. ${ }^{35}$

The Atlantic thus began a trend of viewing Arturo Giovannitti the author around the "masterpiece" of "The Cage" - IWW publicity had already established the centrality of "The Walker" before and during the trial - and of assessing his work as what Louis Untermeyer would later call poetry "in spite of itself," although the perceived obstacles to poetic beauty varied according to the source. ${ }^{36}$ In July 1913 two other journals reprinted "The Cage." The Outlook offered a more lengthy analysis, characterizing the poem as "the voice of a man at war with history" and noting that "curiously enough, in condemning our civilization he adopts bodily one of civilization's most time-honored delusions ... the 'Golden Age' of labor." ${ }^{37}$ Thus, the writer concluded, Giovannitti was brilliant as a verse writer, but as a social critic he was not only a fool but an ingrate, since he attacked the courts which acquitted

34 "The Poetry of Syndicalism," Atlantic, June 1913, 853-4. Nearly fifty years later Max Eastman felt compelled to remark in Love and Revolution that Ellery Sedgwick had published "The Walker" "through some caprice of sympathy." (76) Although it was "The Cage" that was published in the Atlantic, Eastman's memory of the surprise many liberals felt is correct. The Outlook for July 1913 begins its reading of "The Cage" by remarking on its incongruous appearance in the Atlantic: "We say 'lurks' advisedly, for the poem is there purely on editorial sufferance." ("A Poet of the IWW," Outlook, 5 July 1913, 504-6). Notably, the Outlook, though supposedly more progressive, affirms some of the Atlantic's political criticisms, and adds a few of its own, such as the suggestion that "William Wood has as much reason to quarrel with the fundamental principles of the law as Arturo $M$. Giovannitti. Both have been charged with crimes which they did not commit, and both have been acquitted." (506) Driven by the liberal imperative to see two sides to every story, the Outlook claims that the power relations are exactly the same in both cases, although Wood was a mill owner who tried to sabotage a strike by paying men to plant dynamite in buildings occupied by strikers, and Giovannitti was an immigrant charged with being an accessory to a murder committed by police officers.

35 "The Poetry of Syndicalism," Atlantic (June 1913), 853-4.

36 Lewis Untermeyer, The New Era in American Poetry (New York 1919), 184.

37 "A Poet of the IWW," Outlook, 5 July 1913, 504-505. 
him. Current Opinion began a practice, which was to continue in its pages for several years, of publishing and praising Giovannitti's work with relatively little qualification; it observed, "it is a poem of syndicalism and the tone of it is decidedly sombre. Yet it carries its own message of beauty and the message is a sincere and convincing one." ${ }^{38}$ By December of 1915, when "Malabolgia" appeared in its pages, introductory remarks about Giovannitti's work in Current Opinion had taken the form of good-natured ribbing: "As a rule, his words should be printed in red ink, to suit their radical character. But the following poem (from the New York Evening Sun) ends in a note of high patriotism, surprising in a writer of his anarchistic tendencies." ${ }^{39}$

On the left, the IWW and radical socialists worked to regain the critical edge of Ettor's and Giovannitti's representations of the trial. In 1913 the addresses to the jury were published separately and together with "The Walker," "with the hope that the words of the defendants may inspire others to higher thoughts and nobler deeds and thus hasten the day when human happiness will be placed above the dollar." ${ }^{40}$ The Boston School of Social Science also published Charles Zueblin's "Massachusetts on Trial: Massachusetts Acquitted," a folded poem card which summarized the trial and reiterated the "verdict" in its refrain:

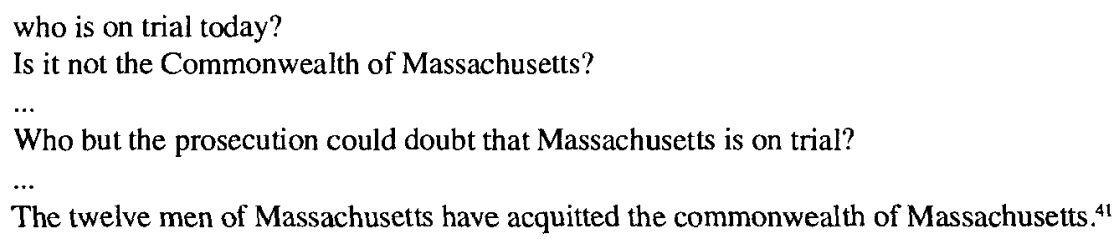

In April 1913 the IWW published Justus Ebert's The Trial of a New Society, reminding the public of Giovannitti's insistence that "whether you want it or not, we are the heralds of a new civilization." Ebert argued that the trial was a sign that the new society desired by the IWW was beginning to triumph, and that, therefore, its social critiques were valid and its prophecies potent. Reading the trial in conjunction with a lengthy analysis of the Lawrence strike as an example of "Industrial Democracy" at work, Ebert interprets them through the IWW preamble: "it was the trial of a new society that is growing out of the old society now prevailing." 42

True to form, Giovannitti's first book appeared with an introduction by Helen Keller, herself the object of discursive struggles between left and Right. Widely recognized by mainstream audiences as an innocent young woman, deaf and blind, the widely acclaimed sign-language pupil of Anne Macy Sullivan, Keller had recently

38 "The Cage," Current Opinion, July 1913, 56.

39 "Malabolgia - A Glimpse of Mulberry Street," Current Opinion (December 1915), 430-31.

40 Ettor and Giovannitti, 6.

41 Charles Zueblin, "Massachusetts on Trial: Massachusetts Acquitted," Poem on folded sheet (Boston 1913).

42 Justus Ebert, The Trial of a New Society (Chicago 1913), 5. 
made a new name for herself in respectable circles by joining the Socialist party, visiting strikes at Lawrence and Little Falls, and proclaiming in her role as a member of the Massachusetts Commission on the Blind that over half of the blind women in Massachusetts had become so through infection with syphilis, which, she maintained, they had contracted because their below-subsistence level wages in industry had forced them to work as prostitutes. ${ }^{43}$ Keller's introduction to Arturo Giovannitti's Arrows in the Gale (1914) is both defensive and directive; she begins by stating that the poet

has tried to render his ideas of the world he lives in. As a poet he is to be judged by his success in rendering these ideas in verse, and not by his relations to Syndicalism or Socialism or any other movement in which he happens to be active. The laws of poetic beauty and power, not one's beliefs about the economic world, determine the excellence of his work. ${ }^{44}$

From here she goes on to discuss Giovannitti's poetry exclusively in terms of his political connections and resistance to unjust laws, without a single sentence about the transcendent beauty of his work. The apparent contradiction may be understood as resulting from the combination of an obligatory gesture towards the poetry establishment of the time with the American left's own untheorized practices with regard to poetry; certain characters in the history of the left are revered because they are poets, but assessments of their accomplishments have more to do with the drama of public relations and popular memory than with the contents of particular poems.

Mainstream critics, for their part, took the bait and worked out the contradiction for themselves. The unstated but felt truth that tempers their critiques of Giovannitti's work and troubles their relation to the poetry is the knowledge that Syndicalism and Socialism were not merely movements "in which he happens to be active." A response which paradoxically accepted the terms of Keller's pronouncement but foregrounded its limitations, pointing to the impossibility of disinterested criticism, (and promptly deflected the issue of politics into the precedents of a distant literary history by invoking Shelley's critical reception) appeared in the Survey. Florence Converse introduces the above passage in her review of Arrows in the Gale with "Helen Keller ... wisely reminds us ..." then argues, "But did any critic, however well meaning his intentions, ever succeed in judging a poet merely by 'the laws of poetic beauty and power'?" 45

Arrows in the Gale appeared and was invested with significance by its first readers in this context of struggles over the interpretation of the trial (and by implication, the strike). The title was an appropriate one - in the "storm" of propaganda surrounding the Lawrence strike and the IWW in general, poems seemed an unlikely if not

43 Robert E. Snyder, “Women, Wobblies, and Workers' Rights: the 1912 Textile Strike in Little Falls, New York," in Joseph R. Conlin (ed.), At the Point of Production: the Local History of the I.W.W. (Westport, CT 1981), 38.

44 Arturo Giovannitti, Arrows in the Gale (Riverside, CT 1914), 3.

45 Florence Converse, Review of Arrows in the Gale, Survey, 27 June 1914, 346-7. 
primitive choice of weaponry, but the environment of their circulation added to their power and increased the chances that they would reach unexpected targets. Critics found their work complicated yet again, because Giovannitti's freshly hostile verses troubled the foundations not only of his public image, but of conservative discourses about the trial.

In Giovannitti's address to the jury he had represented himself as a potential victim and downplayed the antagonism of his political allegiances. He had persuaded the jury that the IWW laid claim to all of America's true values, and despite the lingering traces of uneasiness this change of tone left among critics, his image as a "noble" man had prospered. His translation of and approving introduction to Emile Pouget's Sabotage, in which he claimed that sabotage is the worker's rightful expression of dignity and "manhood," was politely ignored in this atmosphere. ${ }^{46}$ However, Arrows in the Gale served as a reminder that there was a war on - the class war. Everyone agreed that something of major significance had happened at Lawrence, and Giovannitti once again used his power to disrupt conservative truths and to give credence to the IWW interpretation. The "young man of good family, well educated and deeply religious" had to be reconciled somehow with the author of the following lines from the "Proem" of Arrows (published elsewhere under the title "Songs of a Revolutionary"):

If what I have I give, you can

Be sure I lay no heavenly store,

And what I take from any man

I have no thankful feeling for.

All that you worship, fear and trust

I kick into the sewer's maw

And fling my shaft and my disgust

Against your gospel and your law. ${ }^{47}$

In a later poem, "Samnite Cradle Song," a mother croons to her infant to "Die like a man by the ax or the rope/ Spit on their God and stab our good king," vaguely summoning the memory of Gaetano Bresci, who lived for a while in the Italian anarchist community of Paterson, New Jersey before returning to Italy to assassinate King Humbert. ${ }^{48}$

Part of the work judges of the poetry had before them was to decide how to make their assessments in the face of this new evidence of Giovannitti's warlike, uncivil intentions. Their comparisons between his voice and more familiar poets took a different turn. For example, Florence Converse's review in the Survey notes that these "verses that sting and accuse" are appropriately titled - "these verses are indeed winged things, and barbed." But since she is primarily interested in discussing his work as poetry, "exalted and simple," she recuperates the antagonism of his work

46 Arturo Giovannitti, (trans. and intro), Emile Pouget, Sabotage (Chicago 1913), 26.

47 See also "Songs of a Revolutionary," Current Opinion, July 1914, 54.

48 Ibid., 73. 
into a Christian narrative somewhere between the parable of the sower and the archetypal prophet: "Despite the adverse winds of indifference and hostility, some of them will lodge and rankle in human hearts. For the poet unmistakably meant to sting and wound; to let blood; in all the lyrics we hear the Baptist's cry, 'Repent!" By the end of her review, the "voice crying in the wilderness" interpretation has taken a turn toward condescension on the basis of youth: "these twenty-four poems are like the tentative carolings of young birds. Our singer is trying to find his range." 49 Similarly, Harriet Monroe's review of Arrows in Poetry magazine begins by noting the hostility the book is likely to arouse in its readers, but she interprets the poems in hopeful terms of the potential eugenic benefits of changing immigration patterns:

It may be that the future of the arts in America is in the hands of these immigrants and their variously intermarrying children; that they will endow us with that quick expressiveness, that enthusiasm for beauty, that warmth of passion, which have been chilled out of Angle-Saxon [sic] blood by ten centuries or more of British fog..$^{50}$

With a parallel logic she concludes that although this material will probably not make reassuring after-dinner reading for "the comfortable conservative," such readers can be made better people by contact with "this fiery spirit" through these "beautiful forms of power." ${ }^{51}$ In both cases, Giovannitti's work seems hostile, but the hostility is finally subsumed into a moral lesson to liberal/conservatives. Potential benefits to working-class readers do not enter the picture, and the outright class-based antagonism is erased by considerations of the poetry's high quality.

Reviewers whose politics were more in tune with Giovannitti's praised his work on different grounds. Interestingly enough, their favorite poem was neither "The Walker" nor "The Cage" but "The Thinker," a poem inspired by Rodin's statue and preceded by a poem of the same title by James Oppenheim. These reviews opposed the widely accredited opinion that Giovannitti's lyric consciousness conflicted with his IWW work, and argued that his poetry was centred in and central to his radical

49 Florence Converse, Review of Arrows in the Gale, in Survey, 27 June 1914, 346-347.

50 Harriet Monroe, Review of Arrows in the Gale, Poetry, A Magazine of Verse 6 (1915), 37.

51 Monroe, 38. Any doubts about Anglo-Saxon Protestant America's initial response to Italian immigrants during the late nineteenth and early twentieth centuries may be dispersed by a perusal of Salvadore Mondello's The Italian Immigrant in Urban America, 1880-1920, As Reported in the Contemporary Periodical Press (New York 1980). Many of the other accounts of Giovannitti's poetry recuperate his ethnicity into a conflict-free model of liberal pluralism, politely ignore it, or make equally polite references to Italy's classical past. As an example, Florence Converse interprets his sometimes "regrettable" exhuberance as a sign of his origins: "In most of the other poems the poet is not so successful in evading the lure to rhetoric, a temptation peculiarly Italian, as anyone who has listened to the extempore flow of eloquence so impossible to stem at Socialist or other meetings of young Italians." (347) Further, she argues, the flaws or "roughness" in his work must be viewed in the context of his exposure to the lower classes in America: "If he has failed to infuse into his English the subtle Italian grace of a Dante Gabriel Rossetti, the blame must be laid upon the Pennsylvania coal mines and the New York slums, our wells of English muddy and defiled, from which we have forced him to drink." (347) 
politics. The best known example of this treatment is Kenneth Macgowan's "Poet of the Wop," which portrays Giovannitti as an organic intellectual and his poetry as social theory. Macgowan reads Giovannitti's poetry as "the song of the people as he learned it in the Lawrence strike and hummed it over in the jails of Salem. He and his song are products of something that few Americans yet understand ... A poet has arisen to explain." Macgowan takes up with relish the evocations of class struggle, and argues that "Giovannitti is no mere poet of labor," because " the business of his verse is to destroy." Giovannitti's unapologetic embrace of the violent work of the IWW, then, is inseparable from his commitment to poetry, which works for

the individual awakening of "illiterates" and "scum" to an original, personal conception of society and the realization of the dignity and the rights of their part in it. They have learned more than class consciousness; they have learned consciousness of self. The I.W.W. is making the "wop" into a thinker. ${ }^{52}$

In a similar tone, Anna Strunsky Walling maintains that Giovannitti differs from Shelley because he is the poet of a movement: "The idea that is shaping in the minds of the people that freedom and equality can be fought for and achieved is the idea in which he moves and lives and has his being." She also prefers "The Thinker," saying that this "bill of human rights" "has the same still, breathless intensity, an ocean-like vastness and depth" as the statue, and she celebrates the "unerasable sneer" of such poems as "The Prisoners' Bench." Unlike any other reviewer, Walling praises the "Samnite Cradle Song":

So rending is the new art of this poem that one sees all the misery of the world rise up and stalk before one, everybody that has ever been bereaved, shattered, hurt unto death, is included, is remembered.

It is a lullaby that is meant to awaken and not to put to sleep..$^{53}$

\section{"Brothers, it is the things we love ..."}

Giovannitti's poetic "success story" coincided with the IWW's; their appeal to the gaze of the mainstream press declined about the same time as well. By 1919, when Louis Untermeyer included poems by Giovannitti in his Modern Poetry and The New Era in American Poetry, this peak of Giovannitti's career was over, although he would continue to write poems until his death (31 December 1959). The predominating account of his subsequent career is that "he all but disappeared into the outer reaches of an Italian-American labor movement that never recovered from the rollback of the early 1920s." ${ }^{54}$ Untermeyer's inclusion of Giovannitti in his anthologies is often cited as an index of success; I argue that it demonstrates, rather, that not only had the Palmer

52 Kenneth Macgowan, "Poet of the Wop," Forum, October 1914, 609-11.

53 Anna Strunsky Walling, "Giovannitti's Poems," Review of Arrows in the Gale, in New Review, May 1914, 288-92.

54 Paul Buhle, "The Poet-Prophets: Revolutionary Artists in the U.S. from 1870-1930," in Buhle et al, (eds.) Free Spirits: Annals of the Insurgent Imagination (San Francisco 1982), 167. 
raids and sedition trials of the late teens had their effect on journalistic fascination with radical politics, but that discursive structures in the debates about "the laws of poetic power and beauty" had begun to solidify in such a way that mainstream journals were no longer likely to publish Giovannitti's work (the "unerasable sneer" remained with him through the years). In Untermeyer's New Era, for example, which includes four of Untermeyer's own poems and expresses doubt about the future prospects of Ezra Pound, "The Walker" is cut back to excerpts. Untermeyer's introduction of Giovannitti's work celebrates it for its "national" qualities, as "proof of the rich variety and polyphonic character of American poetry," apologizes for its connection with politics, and implicitly belittles its anger as the "eternal rebellion of youth." The repetitive pattern of adjectives in his discussion of Giovannitti's politics takes on the quality of a hostile parody of "The Walker" and suggests that liberal/conservative critics have become bored with this refrain:

The old clash between employer and employed, the tragic and ridiculous enmity between labor and capital, the terrible hypocrisy of "law and order" in many of our mining camps, the absurd fiction of free speech maintained by a "kept" press these are matters which concern the man so deeply that they have forced the poet to ... violate the aesthetic canons. ${ }^{55}$

This "friendly" review was the first to imply that Giovannitti had written something that was not beautiful.

The great irony of Giovannitti's life is that he is exactly the kind of poet the New Critics, who came to dominate critical discussions in University English departments for much of the period from the 1930 s through the $1950 \mathrm{~s}$, purported to admire. ${ }^{56} \mathrm{About}$ this same period, working for the Liberator, he called life "the great forger of chains." His classically poetic disposition lent itself to the simultaneous celebration and despair of mortality which New Critics praised in poets with less skill. The crucial difference, of course, is that he presumed these insights might be of use to mere textile workers. In many ways, his bitter observation of the transformations wrought in him in "The Walker" became a self-fulfilling prophecy. Stricken with paralysis of the legs during the 1950s, he continued to write poems expressing his feeling of entitlement to a life of beauty and intensity and his conviction that he would never be free. Giovannitti published a book of poems in Italian, Quando canta il Gallo, in 1957, and his Collected Poems appeared with an introduction by his friend Norman Thomas shortly after his death. ${ }^{57}$ As Paul Buhle indicates, "Words Without Song" is his best epitaph and his best speech on behalf of the Italian-American workers to whom he devoted his life:

55 Louis Untermeyer, The New Era in American Poetry (New York 1919), 183-4.

56 See Cary Nelson, Repression and Recovery: Modern American Poetry and the Politics of Cultural Memory 1910-1945 (Madison 1989).

57 Sillanpoa 255; see also Poems/Poemas, Agusti Bartra (trans.), Collecion Aquario, Vol. VII (Mexico 1966). 
O distances, rival sisters of the altitudes!

I, who have given up floating on the mists towards the stars

That I might follow the tracks of trains and the hoofs of horsemen,

Shall I forever stay here in the Bronx?

Shall I never see the red linen sails gliding through the amaranth of the Bosphorus?

Shall I never plant a young sapling by an Indian pagoda?

Or beat with my sweaty hands the silences of the Sahara waiting for a human echo?

Shall I never curry a colt at dawn in the plains of the Pampas?

Or turn my back on the minarets of Moscow and follow the wind and say:

The sun is going back to whence I came?

Shall I be forever immobile in the Bronx saying to the tailors and the dressmakers

The glory of man is on the picket line downtown?

And the end of life is two hundred dollars a week? ? $^{58}$ 